\title{
Improving the Teaching and Learning Quality Towards ASEAN University Network (AUN) Standards
} Study in: Postgraduate School of Universitas Negeri Medan

\author{
Bornok Sinaga ${ }^{1, *}$ Sahyar $^{2}$ Darwin $^{3}$ \\ ${ }^{1,2,3}$ Postgraduate School of Universitas Negeri Medan, Jl. Willem Iskandar Psr. V Medan 20221 Indonesia \\ *Corresponding author. Email: bornoksinaga@unimed.ac.id
}

\begin{abstract}
One of the requirements to become a world class university is to have a study program that is recognized by international institutions. Recognition by an international institution in a study program is inseparable from the quality assurance system within the institution. This study aims to develop a quality assurance system in the Postgraduate School of Universitas Negeri Medan (namely: PPs UNIMED) State University based on the ASEAN University Network Quality Assurance (AUN-QA) assessment criteria. The stages are carried out starting from (1) an inventory of eleven AUN-QA criteria and the assessment components contained therein; (2) analysis of the availability and potential of each PPs UNIMED study program prepared to obtain the AUN-QA certificate; (3) Design of program in order to achieve of AUN-QA assessment criteria by eight study programs that have been accredited A in PPs UNIMED and (4) Collecting data, forms and compiling documents to meet the AUN-QA assessment criteria.
\end{abstract}

Keywords: AUN-QA; accreditation; Learning quality, PPS UNIMED.

\section{INTRODUCTION}

The Ministry of Education and Culture of the Republic of Indonesia has issued the National Standard for Higher Education (SN-Dikti) through Regulation no. 3 of 2020, which is regulates the internal and external quality assurance system [1]. The regulation explains that the education, research and service standards that covering of national standards are required to have guidelines for planning, implementing, evaluating, monitoring, quality assurance and activity development as a follow-up evaluation. The quality assurance system includes internal and external quality assurance through accreditation by an institution regulated by the government. As a derivative of this regulation, every study program organized under the Ministry of Education and Culture must be accredited by the National Accreditation Agency of Higher Education (BAN-PT).

Currently, the Postgraduate School of Universitas Negeri Medan (PPs) has managed 24 study programs, 18 of which are master's programs and 6 doctoral programs. Among them, eight study program have been accredited with A level, then 12 study programs have been accredited with B level and the other is 4 study programs are just standing in 2020. The distribution map for the accreditation status of the study program in PPs UNIMED from 2015 to 2015. 2020 can be seen in Figure 1.

Since 2020, eight study programs with an A accreditation have been prepared to participate in accreditation from international institutions. Although the external quality assurance system in the form of international accreditation has not been regulated in Permendikbud No. 3 of 2020, but in Kepmendikbud No. $83 / \mathrm{P} / 2020$ has determined the name/list of international accreditation institutions recognized by the Government of Indonesia [2]. In addition, in the Performance Agreement (PK) document between the Chancellor and the Director of PPs UNIMED it is stated that one of the study programs at PPs UNIMED is targeted to obtain international accreditation plus two study programs are expected to obtain an AUN-QA certificate in 2021. One of the international accreditation institutions recognized by the government namely ASEAN University NetworkQuality Assurance (AUN-QA) is an assessment carried out by university institutions or organizations in ASEAN 


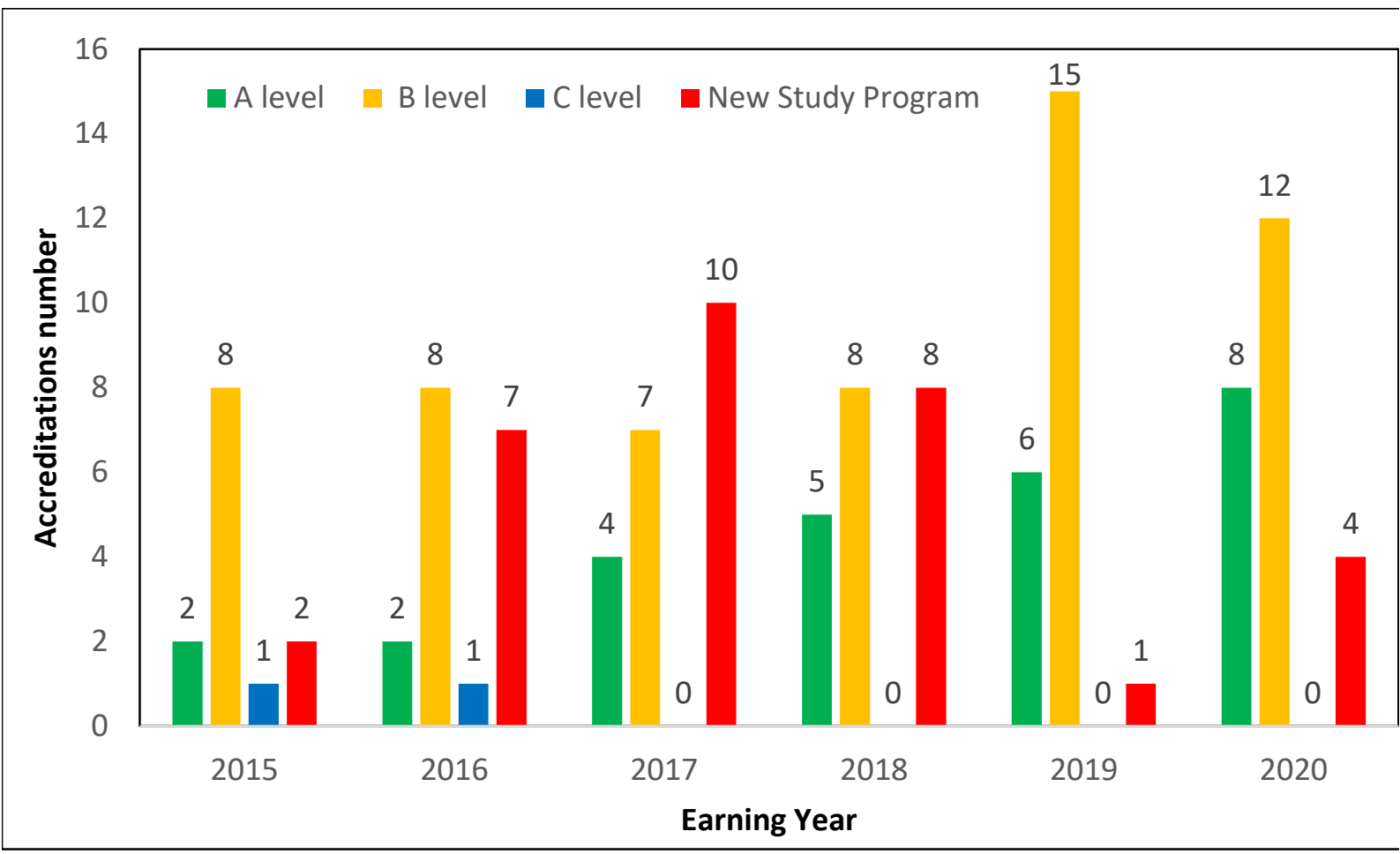

Figure 1. Accreditation status and level of study program that organized by Postgraduate school of UNIMED for $2015-2020$

countries. The assessment is carried out independently by writing a SAR (Self-Assessment Report). AUN-QA refers to international accreditation standards [3]. Based on a search of the AUN-QA assessment guide book version 4.0 , it is known that there are 8 criteria for the assessment system from the program level to obtain a certificate of recognition from the institution including: (1) Expected Learning Outcomes, (2) Programme Structure and Content, (3) Teaching and Learning Approach, (4) Student Assessment, (5) Academic Staff, (6) Student Support Services, (7) Facilities and Infrastructure, (8) Output and Outcomes [4]. In addition to the program level, the achievement of AUN-QA standards is also determined from the results of the quality description assessment. The quality assessment components consist of: (1) Introduction to Quality Assessment, (2) Functions and principles of quality assessment, (3) preparation of a self-evaluation report, (4) self-evaluation report, (5) preparation of quality assessment and (6) process quality assessment.

The existence of a program from the Ministry of Education and Culture together with the Rector of UNIMED to produce international-scale study programs can be realized through the achievement of the AUN-QA certification. As it is known that once the university or study program has been certified by AUN-QA, there will be equality with other high-quality university study programs in ASEAN. In addition, students in AUN-QA certified study programs can transfer credits to other universities that have been certified. For study programs that already hold AUN-QA certification, they will be able to obtain benefits including: 1) Having the opportunity to participate in AUN-QA programs, and/or projects and develop cooperation with ASEAN partner organizations. 2) Adding networks among ASEAN countries and being involved in conferences held by AUN-QA. 3) Opportunities to be involved in AUN-QA workshops and training courses, as well as sharing implementation experiences to improve the quality of higher education [5].

In general, some of the assessment criteria set by AUN-QA such as the criteria for human resources, student affairs, facilities and infrastructure, the structure and content of the study program have similarities with the assessment criteria set by BAN-PT. This condition is an excellent opportunity for PPs UNIMED to encourage study programs that have been accredited A to prepare for obtaining a certificate from AUN-Q. As it is known that there are eight PPs UNIMED study programs that have been accredited A by BAN-PT. So with a capital of nine BAN-PT accreditation criteria that have been achieved, it is hoped that the eight study programs will be able to follow the AUN-QA assessment process in 2021.

In this study, the quality of teaching and learning at the postgraduate school of the State University of Medan has been improved towards the quality standards of the ASEN University Network (AUN-QA). 


\section{METHOD}

The stages carried out in this study began with collecting data related to the number of academic staff in PPs UNIMED. The academic staff at the UNIMED Postgraduate Program are regrouped based on the study program where they work. Grouping based on functional positions and levels of master and doctoral programs is also carried out to determine the distribution of academic staff for each level of education. The distribution of academic staff based on the ownership of professional certificates, visiting professors and as members of the profession is also carried out to determine the recognition and involvement of lecturers in the dissemination of knowledge outside the institution. From the aspect of education and learning, we conduct an analysis of the curriculum. Curriculum development that refers to the Decree of the Minister of National Education of the Republic of Indonesia and towards AUN-QA has been carried out. After the curriculum is developed and implemented in the implementation of learning, then monitoring and evaluation of the curriculum is carried out. The learning process that utilizes the newly developed curriculum refers to the principle of Student center learning (SCL). An analysis of learning platforms that utilize "online learning systems (SIPDA) is also carried out and presented in this study.

\section{RESULT AND DISCUSSION}

\subsection{Academic Staff}

The Graduate School of the State University of Medan (PPs UNIMED) already has a human resource management system that includes planning sub-systems, mapping of lecturer expertise, assignment of lecturers according to their expertise, orientation and placement of employees, career development, transparent and accountable rewards and sanctions based on ability, justice and welfare. The number of PPs UNIMED lecturers in 2019 reached 255 people, with 255 people $(100 \%)$ having doctoral qualifications and having educator certificates. There are 63 PPs UNIMED professors. In lecture services, between study programs do resource sharing of their educative staff, especially the use of available professors. The distribution of lecturers per study program shows that the Mathematics Education Study Program has the largest number of lecturers, namely 29 people and the Basic Education Program (BEP) lecturers have fewer lecturers, namely 5 people. However, lecturers from the Faculty of Education, Mathematics and Natural Sciences, Social Sciences, and Languages participated in giving lectures for subjects for the 7 (seven) concentrations in BEP. The data can be seen in Table 1.

The lecturer distribution of PPs UNIMED based on the functional positions is presented in the Figure 2.

Since 2016, PPs UNIMED has obtained permission to manage 5 (five) Doctoral Programs, namely Doctoral Programs in Educational Management, Chemistry Education, Educational Technology, English Applied Lingustics (LTBI), Fundamental Education (FE). The number of lecturers involved in 5 Doctoral Programs is 48 people as shown in Figure 3. Until now there are 42 lecturers or $(87.5 \%)$ have held the position of professor.

The PPs UNIMED lecturers were actively involved as professional association activities and became the visiting professors at other universities based on their

Table 1. List of permanent lecturers for each masters study program in Postgraduate school of Universitas Negeri Medan based on functional position

\begin{tabular}{|c|l|c|c|c|c|}
\hline \multirow{2}{*}{ No } & \multirow{2}{*}{ Master Study Program } & \multicolumn{4}{|c|}{ Lecturer Positions } \\
\cline { 3 - 6 } & & Asst.Prof & Assoc.Prof. & Professor & Total \\
\hline 1 & English Applied Linguistic EAL & 3 & 4 & 7 & 14 \\
\hline 2 & Educational Technology ET & 3 & 8 & 10 & 21 \\
\hline 3 & Educational Administration EA & 4 & 9 & 8 & 21 \\
\hline 4 & Chemistry Education CE & 6 & 8 & 5 & 19 \\
\hline 5 & Social Anthropology SA & 2 & 4 & 4 & 10 \\
\hline 6 & Economics Science ES & 3 & 5 & 0 & 8 \\
\hline 7 & Mathematics Education ME & 9 & 11 & 9 & 29 \\
\hline 8 & Fundamental Education FE & 0 & 23 & 6 & 29 \\
\hline 9 & Biology Education BE & 2 & 10 & 3 & 15 \\
\hline 10 & Physics Education PE & 1 & 13 & 5 & 19 \\
\hline 11 & Indonesian Education IE & 3 & 3 & 4 & 10 \\
\hline 12 & Sport Education SE & 4 & 10 & 1 & 15 \\
\hline 13 & Accountancy Acc. & 7 & 2 & 0 & 9 \\
\hline 14 & Economics Education EE & 2 & 7 & 1 & 10 \\
\hline 15 & Sport Science SS & 3 & 5 & 0 & 8 \\
\hline 16 & French Education FE & 4 & 7 & 0 & 11 \\
\hline & & 55 & 137 & 63 & 255 \\
\hline
\end{tabular}


expertise. There are 255 people or $100 \%$ of the number of PPs UNIMED lecturers who have professional certificates, then 88 people or $39.1 \%$ of the total lecturers as visiting professors at other universities as shown in Table 2. Moreover, it is known that $100 \%$ of the total lecturers are members of professional associations. The description of the number of Lecturers who have Professional Certificates, Visiting Professors, and Members of Professional Associations is presented in Figure 4.

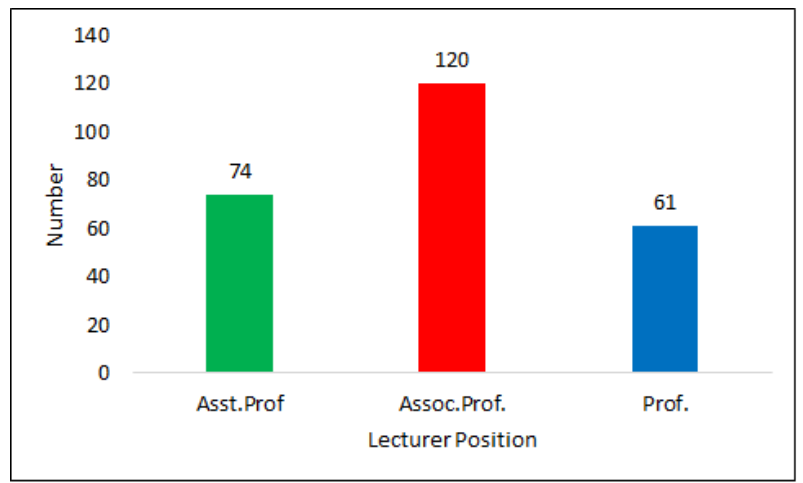

Figure 2. Distribution of postgraduate school lecturer based on functional position

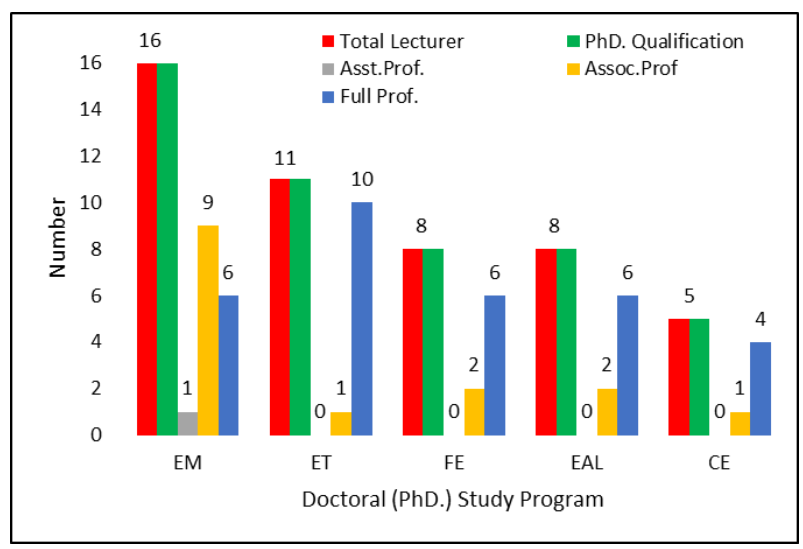

Figure 3. Distribution of lecturer for five doctoral study programs in PPs UNIMED

The study program in the UNIMED Postgraduate Program has lecturers who have met the adequacy and qualification aspects of lecturers according to their expertise. In order to improve the quality of lectures and the quality of graduates, it is necessary to implement a lecturer career development program through the provision of a reasonable workload under 10 credits, attending scientific seminars, study assignments, resource persons for national/international seminars, association members, compilers of national textbooks for junior and high school member. In addition, having and reading books on teaching tips and how to write a better thesis and dissertation, providing proceedings and reputable international journals, as well as providing rewards and punishments as a result of monitoring and evaluation.

\subsection{Achievements in Education and Learning}

The Postgraduate School of UNIMED has implemented the tri dharma of higher education in accordance with the plans set out in the 2015-2019 PPs UNIMED Strategic Plan. The series of achievements have been realized in the field of education and learning as described below.

\section{a. Curriculum Development}

The curriculum of the study program is developed by taking into account four characteristics, namely: (a) flexibility, (b) periodic reviews, which are carried out in part or in whole in accordance with the dynamics of the development of science, technology, arts and sports; and (c) the load of semester credit units (credits) for the education level of the master's program and doctoral program, (d) reflective and adaptive to the demands of the contemporary needs of society.

PPs UNIMED develops the Study Program curriculum in line with existing developments and demands, starting from the Block System CompetencyBased Curriculum, which is the development of the Learning Revolution curriculum (learning revolution) with the application of soft skill integration (character education) based on critical book report assignments, mini research, project and idea engineering).

The curriculum of the Study Program within PPs UNIMED is developed periodically every 4 years, especially in response to the Presidential Regulation Number 8 of 2012 concerning the Indonesian National Qualifications Framework and the Regulation of the Minister of Education and Culture of the Republic of Indonesia Number 73 of 2013 concerning the Application of the Indonesian National Qualifications Framework in the Higher Education Sector. Curriculum development was determined after obtaining approval from the Academic Senate of the State University of Medan (UNIMED) with the Rector's Decree Number: 0149/UN.33/LL/2016 concerning the implementation of the KKNI-based curriculum which was implemented simultaneously in the 2016/2017 academic year in all study programs. KKNI-based curriculum development refers to the Regulation of the Minister of Research, Technology and Education.

The curriculum review process carried out by the Study Program is as follows:

1. Conduct a tracer study on the competencies needed by stakeholders by distributing tracer study questionnaires to alumni and graduate users. Curriculum development refers to the external needs of stakeholders. This is evidenced by the involvement of external stakeholders, namely the Education Office, School Principals and Teachers as well as the business and industrial world. 
Table 2. Distribution of lecturers based on possession professional certificate, visiting professor activities, and professional association member

\begin{tabular}{|l|c|c|c|c|}
\hline \multirow{2}{*}{ Master Study program } & \multicolumn{4}{c|}{ Recognitions } \\
\cline { 2 - 5 } & Expertise Certificate & Visiting Prof. & Association Member & Total Lecturer \\
\hline English Applied Linguistic EAL & 14 & 6 & 14 & 14 \\
\hline Educational Technology ET & 18 & 7 & 18 & 18 \\
\hline Educational Administration EA & 21 & 10 & 21 & 21 \\
\hline Chemistry Education CE & 19 & 6 & 19 & 19 \\
\hline Social Anthropology SA & 10 & 2 & 10 & 8 \\
\hline Economics Science ES & 8 & 4 & 8 & 29 \\
\hline Mathematics Education ME & 29 & 10 & 29 & 9 \\
\hline Fundamental Education FE & 9 & 6 & 9 & 15 \\
\hline Biology Education BE & 15 & 7 & 19 & 19 \\
\hline Physics Education PE & 19 & 8 & 10 & 10 \\
\hline Indonesian Education IE & 10 & 4 & 13 & 13 \\
\hline Sport Education SE & 13 & 4 & 9 & 9 \\
\hline Accountancy Acc. & 9 & 4 & 12 & 12 \\
\hline Economics Education EE & 12 & 5 & 8 & 8 \\
\hline Sport Science SS & 11 & 2 & 11 & 11 \\
\hline French Education FE & 8 & 3 & & 8 \\
\hline
\end{tabular}

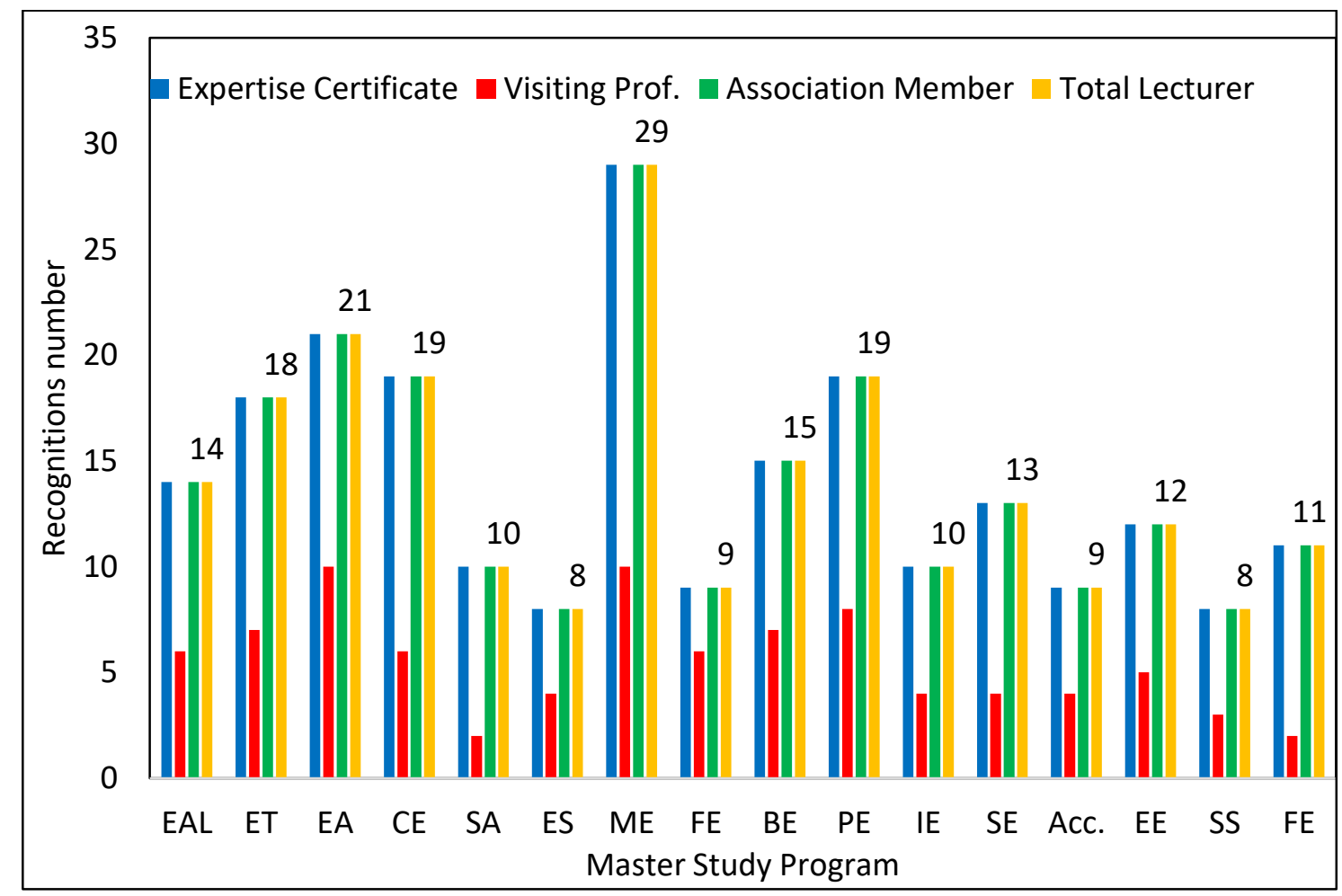

Figure 4. Distribution of expertise certificate, visiting professor, association member and total lecturer each study program at PPs UNIMED

2. Workshop on curriculum development involving internal and external stakeholders to be further aligned with stakeholder needs by taking into account the vision, mission, and feedback of 
Study Program. Curriculum adjustments are made by taking into account the development of science in the field of Education or Non-Education, technological developments and taking into account the needs of stakeholders.

3. In-depth analysis of the competencies needed by stakeholders and comparing them with the competencies contained in the ongoing curriculum by making a competency matrix to find gaps between competencies compared to existing competencies.

4. The survey results are analyzed to be used as the basis for mapping the competencies needed by stakeholders.

5. The team's findings were followed up by the Expertise Lecturer Group (KDBK) through a Focus Group Discussion (FGD) by inviting experts on their respective scientific competencies. The KDBK team is tasked with improving the composition of courses that are adjusted to the expected competencies, course distribution and syllabus revisions.

In the curriculum development, all study programs within PPs UNIMED refer to the level descriptor of the Indonesian national qualification framework (KKNI) by developing levels of learning outcomes, starting from the university level (university learning outcomes), PPs UNIMED level, study program level (program learning outcomes), and course learning outcomes that are aligned with each qualification level. Furthermore, so that UNIMED graduates are of superior quality and able to compete in the life of the 21 st century, 8 (eight) academic competencies of UNIMED graduates are formulated, namely: (1) competent in logical and analytical thinking in problem solving; (2) competent to work independently and cooperate with others; (3) competent in communicating ideas and information orally or in writing; (4) competent to improve knowledge and skills independently; (5) competent to master and use technology; (6) competent in evaluating, analyzing data, and making effective solutions to overcome problems; (7) competent to plan and organize activities; and (8) competent to adapt to the work environment and society. In addition to these 8 (eight) competencies, the requirements for graduates of the master's program are (a) to complete a minimum of 36 credits, (b) to have a minimum TOEFL score of 475 , (c) to have a minimum of 2 (two) speaker certificates at national and international seminars, and ( d) have at least 1 (one) publication of thesis research results in an accredited national journal or a medium indexed international journal. Furthermore, the requirements for graduates of the doctoral program are (a) complete a minimum of 42 credits, (b) have a minimum TOEFL score of 550, (c) have a minimum of 4 (four) speaker certificates at national and international seminars, and (d) have a minimum of 1 (one) publication of dissertation research results in reputable international journals (Scopus indexed).

All Study Programs at PPs UNIMED have also integrated character competencies in their learning process to realize the slogan "Character Building University" so that lecture planning documents such as syllabus, lecture contracts, and Semester Lecture Plans for each course in the Study Program, since 2010 have included soft skills attributes. and character, as well as the scientific themes that knit them.

Referring to the competency of graduates, the next step is to formulate the competency of Graduates and Study Program graduates in PPs UNIMED. The longterm goals to be achieved by PPs UNIMED are: (1) To produce excellent and professional graduates in the fields of education and research; (2) Produce, develop, and disseminate science, technology, arts, and/or sports; (3) Produce and develop innovative and productive works; (4) Produce research with humanities values to promote general welfare and educate the nation's life; and (5) Produce graduates with character, intellectual intelligence, and national insight among the PPs UNIMED academic community. The overall development of the UNIMED PPs curriculum can be described in the scheme as shown in Figure 5.

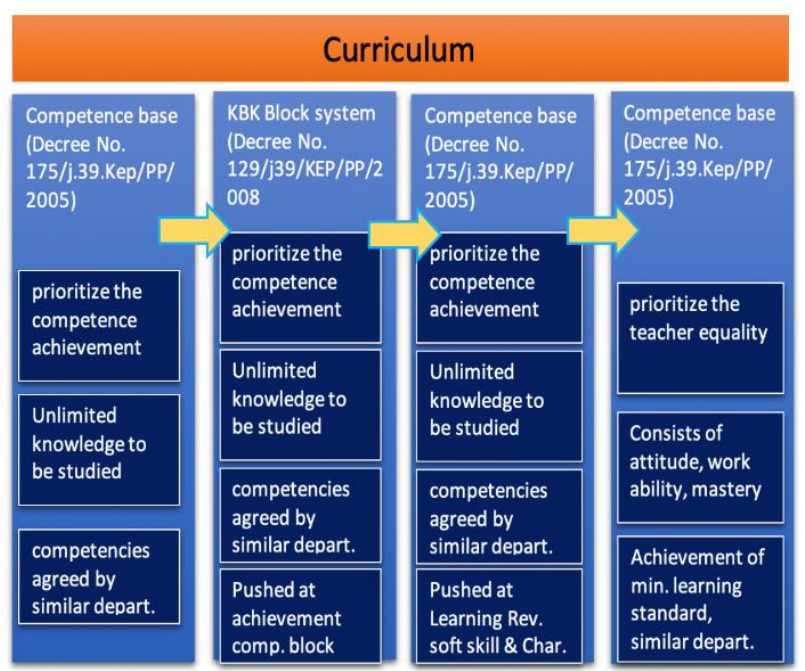

Figure 5. Curriculum development flow at PPs UNIMED

To ensure the relevance of curriculum content development to the needs of graduate users and the development of science and technology as well as to answer the vision, mission of UNIMED and the study program, the study program is facilitated in the planning process through activities (1) FGD involving various internal and external resource persons, (2) tracer study on users graduates representing DUDI, Government and Private Agencies, (3) comparative studies to similar PTNs, (4) FGD with Professional Associations, and (5) Preparation of KKNI documents and learning tools, (6) 
Implementation of PBM internal monitoring and evaluation (MONEV) to oversee the realization of the implementation process, (7) FGD with the Faculty and University Senate to obtain legal acceptances.

Curriculum planning and development activities consist of: (1) compiling Study Program Specifications; (2) compiling learning outcomes (learning outcomes); (3) compiling curriculum content and structure to the distribution of courses, and (4) developing curriculum tools: teaching materials, assessment process, teaching media, student worksheets and assignments, as outlined in the Lecture Contract and RPS. In order to achieve the goals of KKNI and UNIMED's vision and study program vision, the development of this curriculum is based on the results of the tracer study as the basis for determining the profile of graduates, the agreement of associations of similar study programs, as well as the needs for economic, social, and local cultural growth of North Sumatra in determining learning outcomes. /LO). CP/LO mapping in accordance with the scientific competencies contained in the study program, is carried out to align with the KKNI CP/LO standards and the determination of courses and credit load for each course.

Curriculum development based on KKNI and SNPT, and based on learning outcomes and character education in all study programs has produced curriculum documents, including: 1) Academic Manuscripts; 2) Curriculum Structure; 3) Syllabus, Lecture Contract (KP), and Semester Lecture Design (RPS); 4) Assessment System; and 5) Quality Assurance of Curriculum Implementation. Other supporting documents that assist the implementation of the IQF through assessment guidelines/guidelines, student worksheets based on 6 (six) assignments and assessment rubrics for knowledge, skills and attitudes. To increase student learning independence, UNIMED has taken a policy to implement 6 (six) assignments as follows:

1. Routine Tasks (TR): tasks that are routinely given by lecturers to train certain attitudes, knowledge and skills.

2. Critical Book Report (CBR): Description and analysis of the contents of the book, conclusions and students' critical position.

3. Research Review (RR)/Journal Review (JR): reviews all components that critically analyze the main findings, strengths and weaknesses of the research.

4. Mini Research (MR): simple research that at least consists of questions (hypotheses, main objectives), theories, instruments, data collection, data analysis, conclusions.

5. Idea Engineering (RI): "wild idea", creative idea.
6. Project (PR): treatment of certain models or products and practices.

\section{b. Curriculum Monitoring and Evaluation}

Monitoring and evaluation of the curriculum at UNIMED is carried out by Institute Educational Development and Quality Assurance (LP2MP) through the Curriculum Development Center (PPK). The mechanism for monitoring and evaluating the curriculum is based on the procedure manual.

The implementation of curriculum monitoring and evaluation is carried out in each study program through the collaboration of the Study Program Quality Assurance Team and the Quality Assurance Group (GPM) in terms of curriculum development carried out by the Study Programs, carried out in an integrated manner starting from the University - Postgraduate and Study Programs, then reviewed by the Education Quality Assurance and Development Institute (LP2MP). ) university level in collaboration with the Graduate Quality Assurance Group (GPM) and the Quality Assurance Team (TPM) in the study program. This activity aims to see the suitability of the structure format in the curriculum document which refers to Ministry of National Education regulation Number: 44/2015 specifically articles 12,13 , and 14 . MONEV is carried out to see the conformity and compliance of the format with the curriculum preparation guidelines in accordance with the article. The implementation of the learning stages is adjusted to the Semester Learning Plan (RPS) and Lecture Minutes (BAP). MONEV is carried out in two directions by distributing questionnaires to lecturers and students. This is done to obtain data on the achievement of the formulation of graduate competency standards that have been designed with the learning outcomes carried out.

Curriculum evaluation in PPs UNIMED is also carried out to determine the effectiveness and efficiency of curriculum implementation. In addition, curriculum evaluation also aims to determine the achievement of the plan and conformity with the established procedures. For this reason, several monitoring and evaluation documents have been implemented, namely: (1) Monitoring and Evaluation Guidelines, (2) Monitoring and Evaluation Instruments, (3) Monitoring and Evaluation Reports, and (4) Follow-up Documents. Curriculum evaluation is carried out at the end of each academic year.

The monitoring and evaluation instrument for curriculum development consists of 2 (two) aspects, namely: (1) aspects of the achievement of planning and learning in using the curriculum at the beginning and end of the semester, and (2) aspects of curriculum relevance, suitability and updating. The aspect of achievement using the curriculum is mostly evaluated using the analysis of the results of the Internal Quality Audit (AMI) which is carried out at the end of each academic year. Assessment 
techniques used in evaluating designs in curriculum development are in the form of questionnaires, interviews, observations, and document analysis. If there are findings that are not in accordance with the curriculum document, the PPK asks for clarification and the faculty as the learning organizer is obliged to follow up.

\section{c. Learning Process}

The learning approach at UNIMED uses an instructional system that refers to the provisions of the University, namely KBK with the characteristics of increasing the Student Center Learning (SCL) which provides broad learning opportunities for students in order to realize the expected competencies. To ensure the relevance of graduate competence with stakeholder qualifications, the KBK was developed with reference to the Indonesian National Qualifications Framework (KKNI) as a graduate competency standard. Presidential Decree No. 8 of 2012 concerning the Indonesian National Qualifications Framework (KKNI) is the government's response, which sets standards for grading learning outcomes by measuring the outputs of formal, nonformal, informal education, or work experience in the context of recognizing work competencies in accordance with the work structure in various sectors [10]. KKNI becomes the main reference in determining the competence of graduates of academic education, vocational education, and professional education.

Competency-Based Curriculum which refers to the Indonesian National Curriculum Framework (KKNI) and the National Higher Education Standards (SNPT) has been formulated by UNIMED to respond to existing developments as stated in the Regulation of the Minister of Research, Technology and Higher Education Number 64 of 2017 concerning Minimum Service Standards Medan State University [11]. The learning process at UNIMED is carried out by including the results of research on one element of learning content as an effort to bring students closer to the latest developments from research results. For this reason, the learning process is further enhanced by giving six tasks, namely (1) Routine Tasks (TR), Critical Book Report (CBR), Critical Journal Review (CJR), Mini Research (MR), Idea Engineering (RI), and Tasks. Project (TP).

With the six assignments given, students have sufficient scientific competence, enrich scientific insight, research insight, critical thinking based on actual developments, conduct research, develop and engineer innovative ideas and are able to work on project assignments. Thinking competencies that are required are also not only at the level of mastery and application but must be able to think at a high level by adhering to the High Order Thinking Skills (HOTS) pattern. HOTS is part of the cognitive domain in Bloom's Taxonomy which was later revised by Lorin Anderson, David Karthwohl, et al with levels (1) Remembering (remembering), (2)
Understanding (understanding), (3) Applying (applying), (4) Analyzing (analyzing), (5) Evaluating (evaluating), and Creating (creating). Levels 1 to 3 are categorized as low-order thinking skills (LOTS) while levels 4 to 6 are categorized as high-order thinking skills (HOTS) [12 14].

The consequence of the demands for achieving a high level of competence is to prepare supporting facilities for an effective lecture process. UNIMED has carried out various developments in an effort to support the implementation of an effective learning process, both through improving facilities and infrastructure. Teaching materials and learning resources continue to be developed, coupled with the support of the UNIMED Digital Library which is quite representative in supporting the implementation of an effective lecture process through digital teaching material content and modern service systems. In addition, UNIMED has implemented the Blended Learning System for the implementation of face-to-face and online lectures. Faceto-face lectures are conducted in the classroom, laboratory or in the field, while online lectures are conducted through the Online Learning System (SIPDA) application which can be used by all lecturers and students via https://sipda.UNIMED.ac.id./ as viewed in Figure 6.

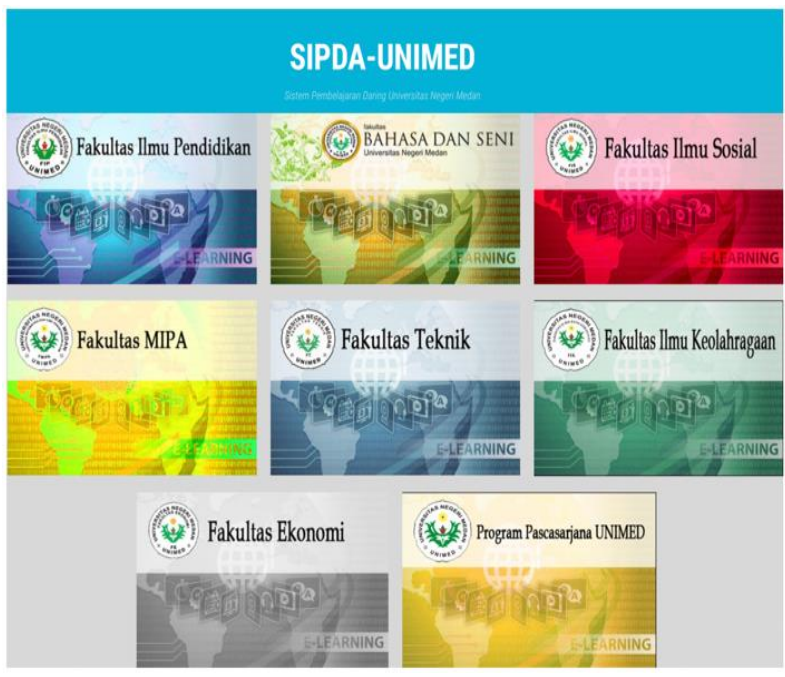

Figure 6. Online learning platforms that applied in State University of Medan

Blended learning has obtained results with significant learning outcomes. In the academic year 2018/2019 blended learning has been carried out by $20 \%$ of lecturers, and the number continues to increase to $50 \%$ of lecturers in 2019/2020. In terms of quantity, the number of courses/classes of study increased from $50 \%$ in the implementation of blended lectures in 2019 to $70 \%$. PPs UNIMED continues to improve this blended learning system learning model through various aspects, especially digital teaching materials, multimedia learning, internet access devices and bandwidth capacity as needed. 


\section{CONCLUSION}

A study of the achievement of ASEAN University Network (AUN) standards has been carried out for the criteria for education and learning at the Postgraduate School of the State University of Medan. Some aspects of the treatment to improve the quality of education and learning are aspects of the distribution of academic staff in each study program organized by the PPs UNIMED. This aspect of academic staff is divided into several sub studies including the number of lecturers with doctoral qualifications as many as 255 people (100\%), lectors 55 people $(21.56 \%)$, head lectors as many as 137 people $(53.77 \%)$ and professors as many as 63 or $(24,700)$. Another sub-aspect is the number and distribution of lecturers who serve as academic staff in the doctoral program as many as 48 lecturers. Based on the search results, it was found that $100 \%$ of the lecturers on duty had professional certificates, as many as 88 lecturers had been invited as visiting professors and 225 lecturers registered as members of the professional association. To achieve the AUN-QA criteria in the learning criteria, curriculum development has been carried out based on the Indonesian National Qualifications Framework (KKNI) which designs six types of tasks, namely routine assignments, critical book reports (CBR), journal reviews, mini research, idea engineering, and projects.

\section{ACKNOWLEDGMENTS}

The authors would like to thank the Universitas Negeri Medan (UNIMED) for the funding supports with contract No. 121/UN33.8/KEP/PPKM/2021

\section{REFERENCES}

[1]. Peraturan Menteri Pendidikan dan Kebudayaan Nomor 3 Tahun 2020 tentang Standar Nasional Pendidikan Tinggi. https://jdih.kemdikbud.go.id/arsip/Salinan\%20PER MENDIKBUD\%203\%20TAHUN\%202020\%20FI X\%20GAB.pdf. Diakses pada 10 Maret 2021

[2]. Keputusan Menteri Pendidikan dan Kebudayaan Nomor 83/P/2020 tentang Lembaga Akreditasi Internasional.

https://ldikti13.kemdikbud.go.id/2020/02/26/kepe mendikbud-no-83-tentang-lembaga-akreditasiinternasional/, diakses pada 10 Maret 2021

[3]. Mulyono, M., \& Amidi, A. (2018, February). Menyongsong Asesmen Aun-Qa. In PRISMA, Prosiding Seminar Nasional Matematika (Vol. 1, pp. 531-538).

[4]. ASEAN University Network, Guide to AUN-QA Assessment at Programme Level Version 4.0, August 2020.
[5]. Mukhaiyar, R., Muskhir, M., \& Dolly, V. P. (2019, November). Curriculum Evaluation based on AUNQA Criterion for the Case Study of the Electrical Engineering Vocational and Educational (EEVE) Study Program. In Journal of Physics: Conference Series (Vol. 1387, No. 1, p. 012039). IOP Publishing.

[6]. Direktorat Jenderal Pendidikan Tinggi, Kementerian Pendidikan Nasional., Sistem Penjaminan Mutu Perguruan Tinggi ( SPM-PT ), Desember 2010

[7]. Direktorat Jenderal Pembelajaran dan Kemahasiswaan Direktorat Penjaminan Mutu. Pedoman Sistem Penjaminan Mutu Internal Pendidikan Akademik - Pendidikan Vokasi Pendidikan Profesi - Pendidikan Jarak Jauh, Kementerian Riset, Teknologi, dan Pendidikan Tinggi, tahun 2018

[8]. Heri Retnawati, Standar-standar dalam ASEAN University Network- Quality Assurance (AUNQA). Disampaikan pada acara Sosialisasi dan Pendampingan Penulisan Self Assesment Report AUN- QA di prodi Pendidikan Luar Biasa Universitas Negeri Yogyakarta tanggal 14 Agustus 2017.

[9]. Abdillah, L. A. (2016). Standar Proses dan Penilaian Pembelajaran (Permenristekdikti No. 44 Tahun 2015 tentang Standar Nasional Pendidikan Tinggi). Weekly Monday Briefing.

[10].REPUBLIK INDONESIA, P. R. E. S. I. D. E. N. (2012). PERATURAN PRESIDEN REPUBLIK $\begin{array}{lllll}\text { INDONESIA NOMOR } & 8 & \text { TAHUN } & 2012\end{array}$ TENTANG KERANGKA KUALIFIKASI NASIONAL INDONESIA.

[11].Peraturan Menteri Riset, Teknologi, dan Pendidikan Tinggi Nomor Nomor 64 tahun 2017, https://jdih.ristekbrin.go.id/viewfile/?id=a3671c61-7f8d-4861-8e3d-18fd6e1d3d50

[12].Sosniak, L. A. (1994). Bloom's taxonomy. L. W. Anderson (Ed.). Chicago, IL: Univ. Chicago Press.

[13].Krathwohl, D. R., \& Anderson, L. W. (2010). Merlin C. Wittrock and the revision of Bloom's taxonomy. Educational psychologist, 45(1), 64-65.

[14].Anderson, L. W., \& Krathwohl, D. R. (2001). A taxonomy for learning, teaching, and assessing: A revision of Bloom's taxonomy of educational objectives. Longman. 